\title{
Influence of convection on stratospheric water vapor in the North American monsoon region
}

\author{
Wandi Yu ${ }^{1}$, Andrew E. Dessler ${ }^{1}$, Mijeong Park ${ }^{2}$, and Eric J. Jensen ${ }^{2}$ \\ ${ }^{1}$ Department of Atmospheric Sciences, Texas A \& M University, College Station, TX, USA \\ ${ }^{2}$ National Center for Atmospheric Research, Boulder, CO, USA \\ Correspondence: Andrew E. Dessler (adessler@tamu.edu)
}

Received: 24 April 2020 - Discussion started: 15 May 2020

Revised: 25 August 2020 - Accepted: 31 August 2020 - Published: 27 October 2020

\begin{abstract}
We quantify the connection between deep convective occurrence and summertime $100 \mathrm{hPa}$ water vapor anomaly over the North American (NA) region and find substantial consistency between their interannual variations and also that the water vapor mixing ratio over the NA region is up to $\sim 1$ ppmv higher when deep convection occurs. We use a Lagrangian trajectory model to demonstrate that the structure and the location of the NA anticyclone, as well as the tropical upper tropospheric temperature, mediate the moistening impact of convection. The deep convection mainly occurs over the Central Plains region. Most of the convectively moistened air is then transported to the center of the NA anticyclone, and the anticyclonic structure helps maintain high water vapor content there. This explains both the summer seasonal cycle and interannual variability of the convective moistening efficiency in the NA region and can provide valuable insight into modeling stratospheric water vapor.
\end{abstract}

\section{Introduction}

Stratospheric water vapor influences both the climate (Forster and Shine, 1997, 2002; Smith et al., 2001; Solomon et al., 2010; Dessler et al., 2013) and chemistry of the atmosphere (Ramaswamy et al., 1996; Evans et al., 1998; Dvortsov and Solomon, 2001; Shindell, 2001; Stenke and Grewe, 2005). Most of the air reaching $100 \mathrm{hPa}$ has traversed the tropical tropopause layer (TTL), where low temperatures typically dehydrate the air to 3-5 ppmv (Mote et al., 1996; Sherwood and Dessler, 2000; Randel et al., 2004; Fueglistaler, 2005; Fueglistaler et al., 2009). However, over the Asian monsoon and North American monsoon, higher water vapor mixing ratios, sometimes exceeding $12 \mathrm{ppmv}$, are observed. This value is much higher than the water vapor mixing ratio in the tropics, indicating that the air did not go through the TTL or is moistened further after leaving the TTL (Anderson et al., 2012; Schwartz et al., 2013; Randel et al., 2015; Smith et al., 2017).

Convection penetrating the tropopause plays a potentially important role in moistening the stratosphere (Dessler and Sherwood, 2004; Dessler et al., 2007; Hanisco et al., 2007; Ueyama et al., 2015, 2018). Previous case studies have shown that deep convection over North America (NA) can reach the lowermost stratosphere (between the local tropopause and the $380 \mathrm{~K}$ isentropic surface) and can even enter the stratospheric overworld (above $380 \mathrm{~K}$ ), thereby bringing a high water vapor content to the stratosphere (Hanisco et al., 2007; Herman et al., 2017; Smith et al., 2017). However, previous studies on the long-term behavior of NA stratospheric water vapor and deep convection conclude that there is little connection (Randel et al., 2015; Sun and Huang, 2015; Kim et al., 2018). Model simulations also cannot reproduce a high water vapor mixing ratio over NA using prescribed global satellite-derived deep convection (Ueyama et al., 2018; Wang et al., 2019).

One crucial issue in these analyses is how high convection extends into the stratosphere. Previous studies based on the infrared satellite cloud-top height measurements are low biased (Ueyama et al., 2018; Schoeberl et al., 2019) owing to the isothermal nature of the lowermost stratosphere and the fact that convective clouds rapidly sublimate in the dry stratosphere and therefore may be missed in observations from polar-orbiting satellites. A better option for estimating cloud-top height over NA is ground-based radar (Liu and 
Liu, 2016; Cooney et al., 2018). The hourly interval GridRad data, derived from NEXRAD radar data, captures convective overshooting events over most parts of the contiguous US (Solomon et al., 2016; Cooney et al., 2018), sometimes extending as high as $22 \mathrm{~km}$.

In this study, we focus on the NA region and use the GridRad data as a convective proxy to study the impact from deep convection on stratospheric water vapor. In the following analysis, we will first show the relationship between the interannual variability of the water vapor and deep convection over the NA region. Then we use a back trajectory model to illustrate the processes that influence where deep convection moistens the NA stratosphere, from the perspectives of spatial distribution, seasonal cycle, and interannual variability.

\section{Data and methods}

\subsection{Data}

The Microwave Limb Sounder (MLS) on board the NASA Aura satellite (Waters et al., 2006) has provided high-quality daily near-global observations of water vapor in the upper troposphere and stratosphere since August 2004. In our research, we use the version 4.2 level 2 product from 2005 to 2016 and focus on water vapor at $100 \mathrm{hPa}$ over the NA region $\left(25-50^{\circ} \mathrm{N}, 70-130^{\circ} \mathrm{W}\right)$. MLS makes roughly 2500 observations over this region every month, and we bin and average these MLS data into a $4^{\circ}$ latitude by $8^{\circ}$ longitude grid after applying quality control (Livesey et al., 2018).

The GridRad dataset archives national NEXRAD WSR88D radar data (version 3.1). Gridrad v3.1 has horizontal resolution $0.02^{\circ}$ longitude and $0.02^{\circ}$ latitude and covers 25 to $49^{\circ} \mathrm{N}$ and 70 to $105^{\circ} \mathrm{W}$, i.e., most of the contiguous US (Homeyer, 2014; Homeyer and Kumjian, 2015; Solomon et al., 2016; Cooney et al., 2018). The vertical resolution of the GridRad data is $1 \mathrm{~km}$, from 1 to $24 \mathrm{~km}$ a.s.l. (above sea level), and it has a temporal resolution of $1 \mathrm{~h}$. Cooney et al. (2018) used GridRad data to calculate the deep convective echo top and found out the highest level that the reflectivity over $10 \mathrm{dBz}$ is a representative threshold that balances the sensitivity and noise. In our analysis, we also use this strategy and identify deep convection as observations of reflectivity over $10 \mathrm{dBz}$.

Finally, we bin the occurrence of convective cloud into a $1^{\circ}$ latitude by $1^{\circ}$ longitude (horizontal) by $1 \mathrm{~km}$ (vertical) grid box, dividing the number of observations that encounter convection by the total number of observations in each grid box.

Temperature, pressure, and tropopause information comes from the European Centre for Medium-Range Weather Forecast (ECMWF) Re-Analysis (ERA)-Interim (ERAi) archived 6-hourly model fields (Dee et al., 2011). The ERAi data are gridded into a $1^{\circ} \times 1^{\circ}$ horizontal grid with 37 vertical lay- ers. To identify the tropopause, we linearly interpolate ERAi temperature into $2 \mathrm{hPa}$ pressure intervals and define the lowest level where the lapse rate is less than $2 \mathrm{~K} \mathrm{~km}^{-1}$ and the average lapse rate between this level and all higher levels does not exceed $2 \mathrm{~K} \mathrm{~km}^{-1}$ to be the tropopause (World Meteorological Organization, 1957).

\subsection{Back trajectory model}

To identify water vapor observations that had previously encountered convection, we use back trajectory analyses. We use temperature, wind, and diabatic heating rate from the ERAi to drive the TRAJ3D Bowman trajectory code (Bowman, 1993; Bowman and Carrie, 2002). Vertical velocities in isentropic coordinates are computed from 6hourly average diabatic heating rates. Horizontal velocities come from 6-hourly instantaneous two-dimensional horizontal wind fields. Several previous studies have successfully identified convectively influenced air masses based on trajectory model driven by reanalysis data (Wright et al., 2011; Bergman et al., 2012, 2013; Smith et al., 2017).

In these experiments, we initialize air parcels at and surrounding the MLS observations made during JuneAugust (JJA) over 2005-2016. The initiation of parcel positions follows the same strategy as Smith et al. (2017): we initiate a cluster of 27 parcels on a $3 \times 3 \times 3$ grid surrounding each MLS measurement $\left( \pm 0.25^{\circ}\right.$ latitude, $\pm 0.25^{\circ}$ longitude, and $\pm 5 \mathrm{~K}$ potential temperature around and at $100 \mathrm{hPa}$ ). We advect the parcels back $5 \mathrm{~d}$ and record latitude, longitude, potential temperature, pressure, and temperature every hour.

After performing the back trajectory model, we then divide the trajectories into two groups, depending on whether the parcels encountered deep convection along the path or not. The definition of encountering deep convection is whether the trajectory is within $\pm 0.25^{\circ}$ latitude and $\pm 0.25^{\circ}$ longitude of a GridRad deep convection observation and when the parcel is below the convection top and above the local tropopause at the time the deep convection is observed. If at least one parcel in the cluster of parcels encounters deep convection, the corresponding observation is categorized as encountering convection; otherwise, it is in the "no-convection" group.

\section{Relationship between area-average water vapor and convection}

In Fig. 1a, we show the time series of $5 \mathrm{~d}$ average $100 \mathrm{hPa}$ water vapor anomaly and $10 \mathrm{~d}$ average convective occurrence, both averaged over the NA region. We have subtracted the JJA zonal mean value from the NA $100 \mathrm{hPa}$ water vapor content, allowing us to focus on the variability in the NA region relative to the zonal average value and minimize the impact of transport from the tropics. 

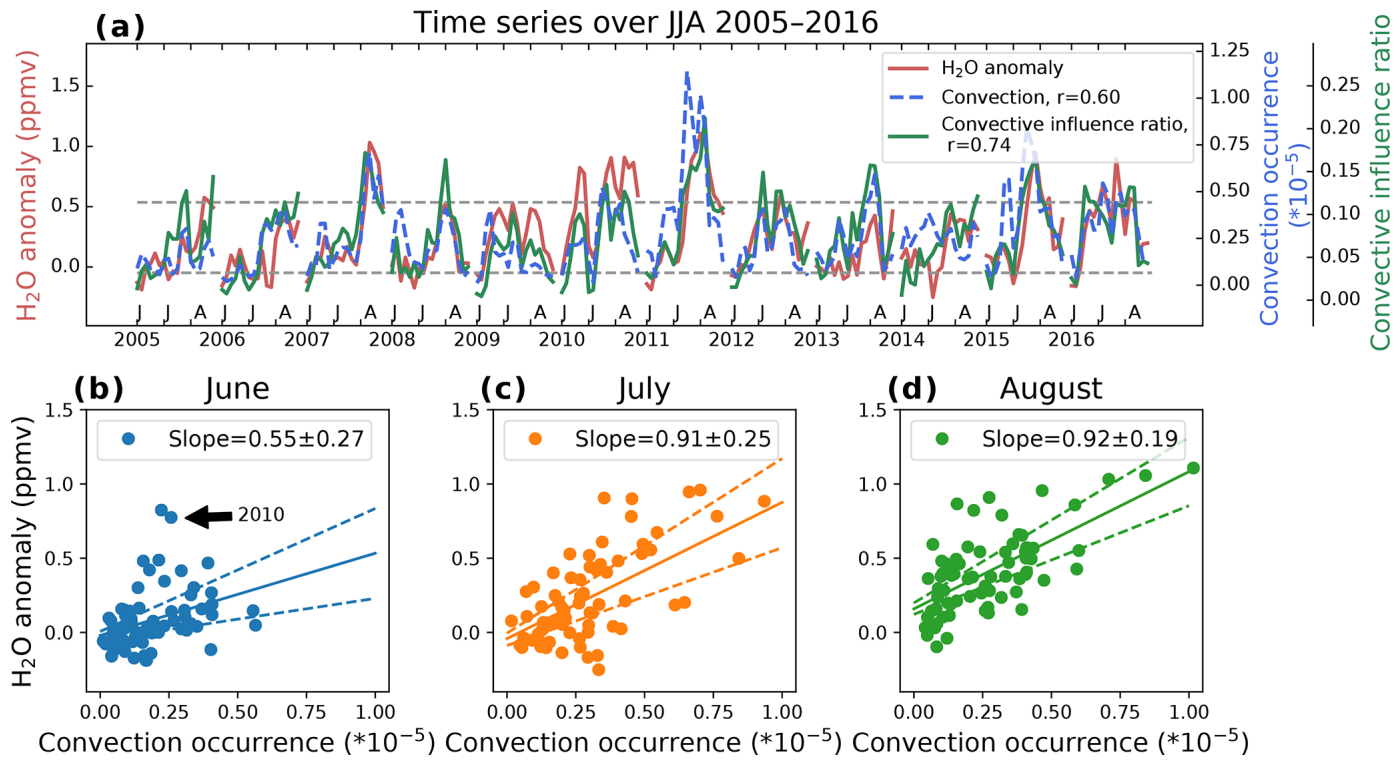

Figure 1. (a) Time series of $100 \mathrm{hPa}$ (red line) MLS water vapor anomaly (zonal mean removed), (blue line) convective occurrence from GridRad, and (green line) the effective convective influence ratio in the back trajectory experiments. All data are $5 \mathrm{~d}\left(\mathrm{H}_{2} \mathrm{O}\right.$ anomaly and influence ratio) or $10 \mathrm{~d}$ (convection) averages over the NA region $\left(25-50^{\circ} \mathrm{N}, 70-130^{\circ} \mathrm{W}\right)$ during June-August 2005-2016. For the convective frequency, we use linear interpolation to estimate the value at $100 \mathrm{hPa}$. The effective convective influence ratio is the fraction of the MLS observations that encounter deep convection and do not get further dehydrated, as determined by the back trajectory calculations. (b-d) Joint distribution of convection and water vapor time series during 2005-2016 divided into (b) June, (c) July, and (d) August. Solid lines show the linear fit, and dashed lines show the $95 \%$ significant level margin of error of the slope bar (accounting for autocorrelation). To account for the time for the water vapor to spread out, each data point is a $10 \mathrm{~d}$ average of convection, with water vapor averaged over the last $5 \mathrm{~d}$ of the averaging period for convection.

Overall, there is a high correlation between the water vapor anomaly and convective occurrence, which suggests that deep convection moistens the stratosphere. However, there are exceptions, e.g., during June 2010, where the water vapor anomaly is high despite deep convection being relatively infrequent.

To make this correlation clearer, Fig. 1b-d show scatter plots of the $5 \mathrm{~d}$ water vapor anomaly and $10 \mathrm{~d}$ deep convective occurrence over NA in June-August. We find that deep convection increases $100 \mathrm{hPa}$ NA stratospheric water vapor by up to $\sim 1$ ppmv. The slope of the linear fit in Fig. 1b$\mathrm{d}$ represents the moistening efficiency, which is defined as the amount of water vapor content added per unit of deep convective occurrence in the month. This moistening efficiency is significantly lower during June than July and August, which we will explain in the next section.

One must be careful not to confuse correlation with causality. We therefore use the back trajectory model to demonstrate the causal relationship implied in Fig. 1. As discussed in Sect. 2.2, we divided the $100 \mathrm{hPa}$ MLS observations into two groups depending on whether or not they encountered the deep convection during the $5 \mathrm{~d}$ back trajectory. Figure 2 shows the probability density function (PDF) of the water vapor mixing ratio during June-August 2005-2016 in the two groups.
We see that the no-convection group has a similar PDF shape in June-August, with peak values around 4 ppmv. For the MLS measurements that encountered convection, the peak of the PDF is 5-6 ppmv during July and August, and 4-5 ppmv during June. The median of the $\mathrm{H}_{2} \mathrm{O}$ mixing ratio in the encounter deep convection group is $0.37,0.62$, and $0.69 \mathrm{ppmv}$ higher than the no-convection group during June, July, and August, respectively.

Our work in this section establishes that deep convection is increasing water vapor over the NA region. However, three questions remain to be answered: first, can deep convection explain the spatial distribution of the water vapor anomaly? Second, why is the convection more effective in July and $\mathrm{Au}-$ gust than in June? Third, why is there interannual variability in the effectiveness of moistening (for example, June 2010 vs. June 2011)? These are three key questions we answer in the following sections.

\section{Differences between June-August}

From June to August every year, deep convection frequently occurs over the central US (Fig. 3a-c; see also Cooney et al., 2018). The water vapor mixing ratio over NA also shows positive anomalies relative to the zonal mean (Fig. 3d-f). However, there is a discrepancy between the spatial distribution 

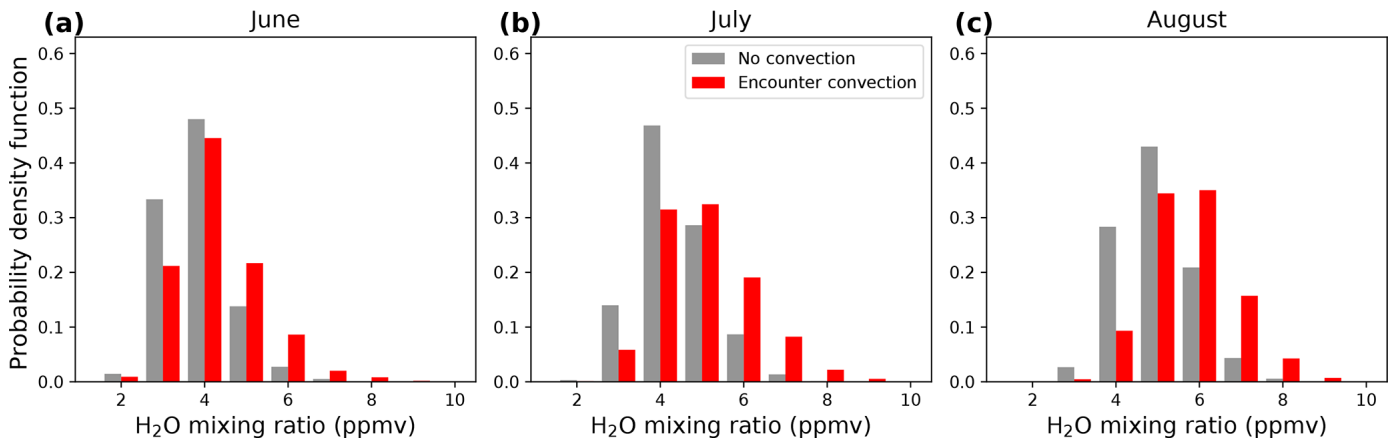

Figure 2. Probability density function of MLS water vapor observations at $100 \mathrm{hPa}$ averaged over NA $\left(25-50^{\circ} \mathrm{N}, 70-130^{\circ} \mathrm{W}\right)$ in $(\mathbf{a}) \mathrm{June}$, (b) July, and (c) August 2005-2016. The observations are divided into two groups: (red) those whose back trajectory encounters convection and (grey) those that do not.

of the water vapor anomaly and deep convective occurrence: the deep convection occurs mainly over the Central Plains region, centered around $40^{\circ} \mathrm{N}$. Large positive water vapor anomalies are observed over a broader longitude range south of $40^{\circ} \mathrm{N}$ latitude.

Our back trajectory calculations show that regions with high convective influence ratios (Fig. $3 \mathrm{~g}-\mathrm{i}$ ) tend to be colocated with large positive water vapor anomalies (the dashed black contours in Fig. 3g-i; see also Fig. 3 d-f). Here, we define the convective influence ratio as the number of MLS observations in each grid box that encountered deep convection during the past $5 \mathrm{~d}$, divided by the total number of MLS observations in that grid box. This collocation suggests that the pattern of enhanced water vapor seen by MLS can be explained by frequent convection. It is worth mentioning that previous studies have also suggested that the water vapor maximum over the NA region cannot be reproduced without the inclusion of convection in the model (Ueyama et al., 2018, their Fig. 3c; Wang et al., 2019, their Fig. 2f).

We identify the locations where parcels encounter deep convection in the back trajectories and grid the number of trajectories encountering convection into $2^{\circ} \times 2^{\circ}$ boxes (Fig. $3 j-$ 1). Most of the locations of convective encounters occur over the region where GridRad data show deep convection frequently occurs, e.g., over the Central Plain region, and over Florida during August. The geographical distribution of convective encounters does not match with the convective influence ratio, indicating that convective moisture is transported to the region of high water vapor by the dynamics of the monsoon.

Also shown in Fig. 3m-o is the NA residence time, as calculated by back trajectory analyses. We initialize the parcel evenly on a $1^{\circ} \times 1^{\circ}$ grid over NA $\left(25-50^{\circ} \mathrm{N}, 70-130^{\circ} \mathrm{W}\right) \mathrm{ev}-$ ery hour during each month and track their positions back $10 \mathrm{~d}$. We then calculate the time from when it entered the NA region to the initialization point and then grid the time of these parcels according to their location of initiation. The NA residence time indicates how long the air parcels in each grid box have been in the NA region. These figures show that parcels at the center of the monsoon have the longest history over NA: a week or longer.

There is also a similarity between the distribution of the time spent over NA (Fig. 3m-o) and the convective influence ratio (Fig. $3 \mathrm{~g}-\mathrm{i}$ ), indicating that the monsoon circulation tends to hold air that has flowed over convection in the NA region. This provides an explanation for the observations in Fig. 3d-f showing that the $100 \mathrm{hPa}$ water vapor maximum tends to be located south of convection.

The monsoon dynamics are also an essential factor in the seasonal cycle of water vapor anomaly. Here, seasonal cycle refers to the increase in water vapor anomaly through the summer, from June to July to August. There are two reasons for this. First, the North American monsoon anticyclone (NAMA) forms in June and enlarges and becomes stable during July and August (Clapp et al., 2019). This leads to increases in the average NA residence time from 3.4 to 4.5 to $4.9 \mathrm{~d}$ from June to August. This increases the convective influence (the fraction of MLS observations that encountered convection), with values in June-August of 0.043, 0.083, and 0.093 , respectively. What is happening here is that later in the summer the convectively moistened air is more likely to be confined within the NA region instead of being transported downwind by the zonal mean flow. As a result, moistening from deep convection becomes less diluted by zonal mean flow later in the summer.

The second reason is also connected to the changing dynamics during June, July, and August. Parcels tend to travel to lower latitudes during June (Fig. $4 \mathrm{a}$ ): $33 \%$ of the convectively moistened parcels travel to the tropics $\left(20^{\circ} \mathrm{N}-20^{\circ} \mathrm{S}\right)$ during June, $13 \%$ travel during July, and $9 \%$ travel during August. Traveling to the tropics leads them to experience colder temperatures at $100 \mathrm{hPa}$ : the median of the water vapor mixing ratio of the parcels that stay in the midlatitudes is 5.98 ppmv, while it is $5.36 \mathrm{ppmv}$ for those parcels that travel to the tropics. The tropical temperature at $100 \mathrm{hPa}$ over June is also colder than over July and August (Fig. 4b). This means that convectively moistened air experiences subsequent de- 

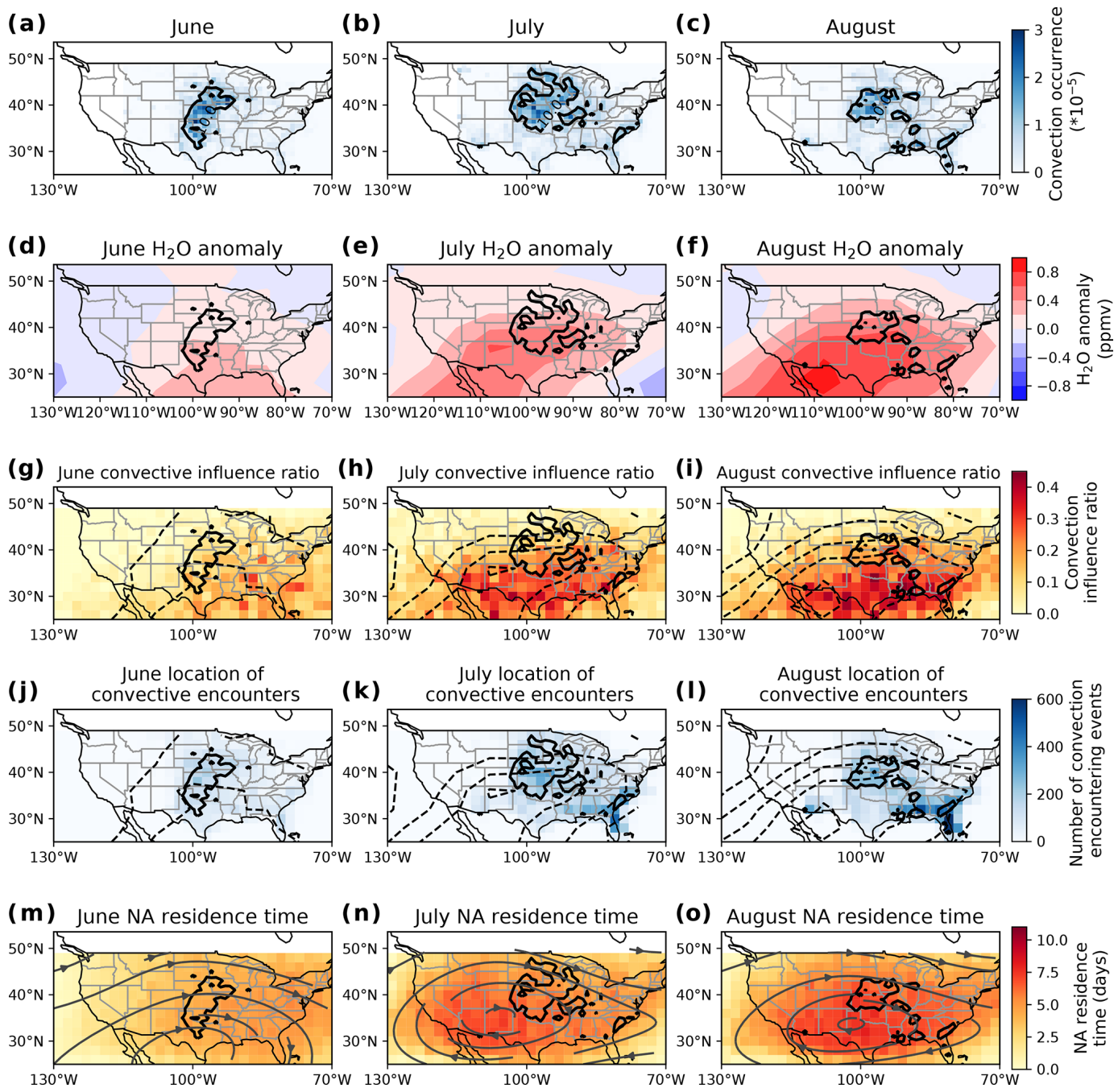

Figure 3. (a-c) Distribution of the $100 \mathrm{hPa}$ GridRad deep convection occurrence averaged over 2005-2016 in (a) June, (b) July, and (c) August. The black contour in each panel (repeated in each row) is the $10^{-5}$ contour of GridRad convective occurrence, averaged over that month. (d-f) Geographical distribution of the MLS $100 \mathrm{hPa}$ water vapor anomaly (after removal of the zonal mean), averaged over 2005-2016 in (d) June, (e) July, and (f) August. (g-i) Geographical distribution of the convection influence ratio over the NA region during (g) June, (h) July, and (i) August 2005-2016. The dashed black contour (repeated in g-l) is the water vapor anomaly contours matching the shading in the corresponding upper panel. (j-l) Location where convectively influenced parcels encounter convection during 2005-2016 (j) June, (k) July, and (l) August. (m-o) Geographical distribution of the parcel time spent over the NA region during (m) June, (n) July, and (o) August. The stream lines are horizontal velocities interpolated onto $100 \mathrm{hPa}$ using the cubic spline method from ERAi data averaged over the same period.

hydration more frequently in June than in later months (Randel et al., 2015).

The PDFs of the minimum saturation water vapor mixing ratio, which limits the amount of water in the parcel, indicates that parcels in June tend to have lower values (Fig. 4c). If we choose a minimum saturation water vapor mixing ratio of 5 ppmv as a threshold of effective moistening (stratospheric water vapor mixing ratio commonly will not exceed this value), then $88.0 \%, 97.8 \%$, and $97.5 \%$ of the observations that encountered deep convection are effectively moistened in June, July, and August, respectively. We calculate the effective convective influence ratio by dividing the number of convectively moistened observations that have a minimum saturation water vapor mixing ratio over 5 ppmv by the total number of observations. The effective convective influence ratio is $0.039,0.082$, and 0.092 during June, July, and August, respectively.

\section{Interannual variability}

Figure 1a shows times series for water vapor, deep convection, and the effective convective influence ratio for June- 

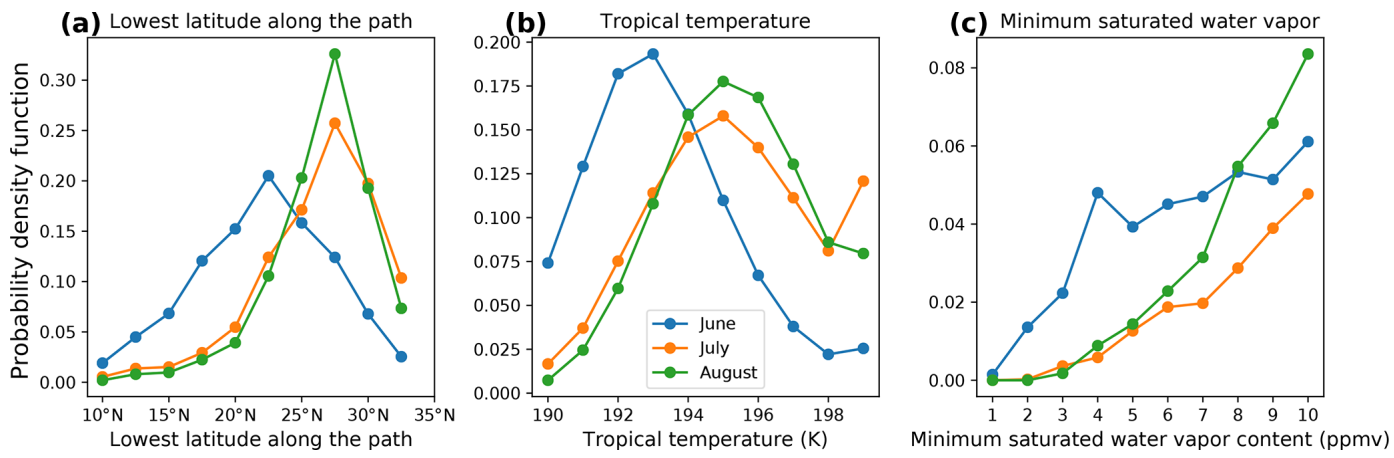

Figure 4. (a) PDF of lowest latitude. (b) Daily tropical temperature (K) obtained from ERAi (0-20 N, 70-130 W). (c) PDF of minimum saturated water vapor (ppmv). The minimum saturated water vapor mixing ratio and the lowest latitude are the minimum values along the path after the parcels encounter deep convection in the back trajectory model and prior to being observed by MLS.

(a) 2010-06-01 to 2010-06-10 (b) 2010-06-11 to 2010-06-20 (c) 2010-06-21 to 2010-06-30

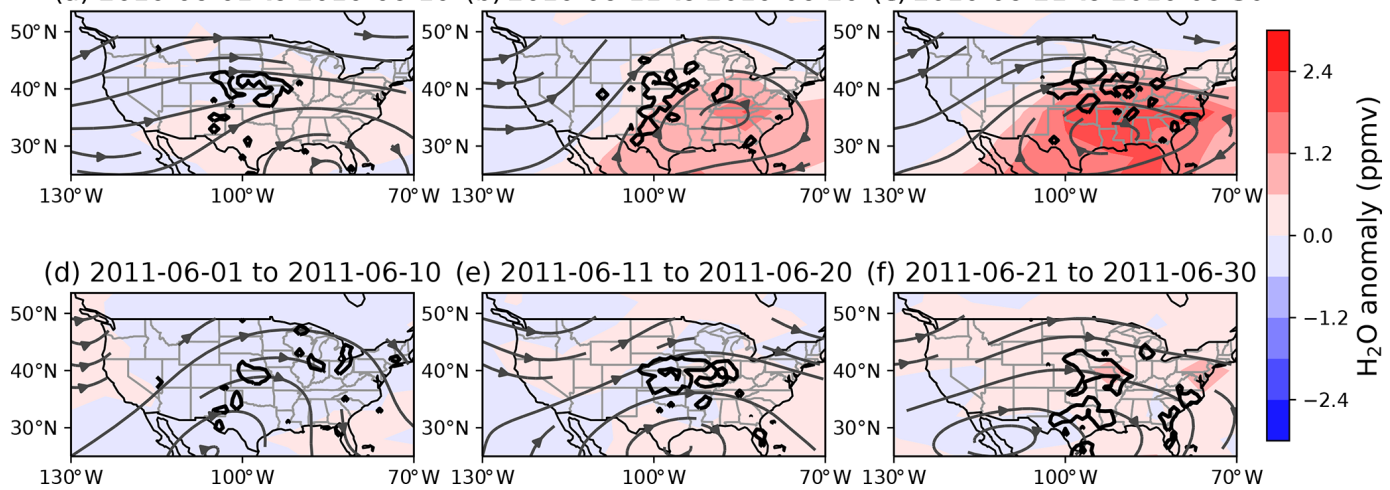

Figure 5. The $10 \mathrm{~d}$ average water vapor anomaly (ppmv) at $100 \mathrm{hPa}$ (after removing the zonal mean) during (a-c) June 2010 and (df) June 2011. Thick black contours are the $10^{-5}$ contours of GridRad deep convection, and stream lines are horizontal velocity at $100 \mathrm{hPa}$ obtained from ERAi averaged over the same period.

August of 2005-2016. The correlation coefficient between water vapor and the effective convective influence ratio time series is 0.74 and is 0.60 between water vapor and deep convection. We show in Sect. 3 that there are clear outliers in the correlation between water vapor anomaly and deep convection, e.g., June 2010 has lower convection but much higher water vapor than June 2011, and the effective convective influence ratio shows a better fit over these months. In this section, we compare these 2 months to illustrate the factors that contribute to the interannual variability of convective moistening.

During June 2010, a stable anticyclone forms over the eastern NA region from 11 to 30 June (Fig. 5a-c). In June 2011, the monsoon anticyclone is located further south, and the NA region is dominated by the westerly winds (Fig. 5d-f). Because of the difference in locations of the monsoon anticyclone, the parcels influenced by convection experience different pathways. In June 2010, $20 \%$ of the convectively influenced parcels travel to the tropics $\left(20^{\circ} \mathrm{N}-\right.$ $20^{\circ} \mathrm{S}$ ) in $5 \mathrm{~d}$, while $44 \%$ do in June 2011 (Fig. 6a). This means that parcels influenced by convection in June 2011 on average experience colder temperatures. Finally, the tropics were slightly cooler during June 2011 compared to June 2010, which further contributed to lower water vapor in NA (Fig. 6b). The net result of these differences is that convectively influenced parcels retain more water vapor in June 2010 than in June 2011 (Fig. 6c) due to differing monsoon dynamics. Thus, monsoon dynamics variability may play a significant role in the generating interannual variability of the convective moistening efficiency on stratospheric water vapor in the NA region.

\section{Conclusions}

In this study, we investigated the contribution of convection to the stratospheric water vapor in the North American (NA) monsoon region, including the seasonal cycle and interannual variation of convective contributions during the Northern Hemisphere summer. We have shown that the deep convection moistens the lower stratosphere, adding up to $\sim 1 \mathrm{ppmv}$ to the summertime NA water vapor at $100 \mathrm{hPa}$ based on the observations from MLS. 

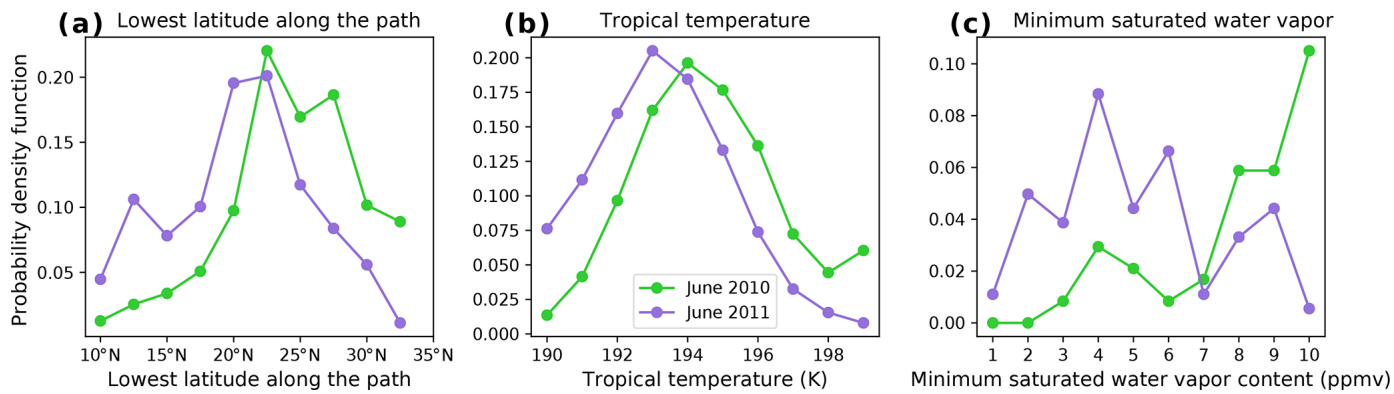

Figure 6. PDF of (a) the lowest latitude along the path in the back trajectory experiments, (b) daily tropical temperature (K) obtained from ERAi $\left(0-20^{\circ} \mathrm{N}, 70-130^{\circ} \mathrm{W}\right)$, and (c) minimum saturation water vapor mixing ratio (ppmv) in the back trajectory experiment results. Minimum saturation water vapor mixing ratios and lowest latitude are the minimum values along the path after the parcels encounter deep convection in the back trajectory model and prior to being observed by MLS.

We have also shown that it is not the amount of convection alone that determines the impact on water vapor: NA monsoon dynamics also play a role. We note that the location of deep convection is not colocated with the maximum water vapor in NA, and this is due to high water vapor content being transported downstream by the monsoon circulation. The maximum water vapor content appears near the center of the NA anticyclone.

We also analyzed the seasonal cycle of convective influence. During June, the NA monsoon circulation is located further south than during July and August, and thus air influenced by convection during June experiences colder temperatures while traveling to the tropics. Subsequent dehydration reduces the net moistening from convection during June compared to the other months studied. Variations in the monsoon dynamics can also lead to interannual variations in convective moistening through a similar mechanism. We compare June 2010 and June 2011 and show that a more northerly monsoon circulation in June 2010 leads to convectively influenced air encountering warmer temperatures, leading to higher water vapor than in June 2011.

Our use of GridRad data as a source of convection is a limitation in our analysis because the dataset only covers the continental US. Much of the monsoonal deep convection also occurs over the Occidental Sierra Madre, Mexican Plateau, and the Gulf of Mexico (Clapp et al., 2019), out of range of the NEXRAD stations. Future studies including convective data with a larger spatial extent may find that the deep convection over the Gulf of Mexico influences NA stratospheric water vapor, but we do not expect this will conflict with the main conclusions from our paper.

Data availability. All code for this project is available from https://doi.org/10.5281/zenodo.4015534 (Yu et al., 2020).

- Deep convection data from GridRad data are available from http://gridrad.org/data.html (last access: 9 October 2020) (Homeyer, 2014).
- Water vapor data observed by MLS are available from https:// mls.jpl.nasa.gov/products/h2o_product.php (last access: 9 October 2020) (Waters et al., 2006).

- Wind, temperature, and heating rate data are from ERAInterim: https://www.ecmwf.int/en/forecasts/datasets/ (last access: 9 October 2020) (Dee et al., 2011).

Supplement. The supplement related to this article is available online at: https://doi.org/10.5194/acp-20-12153-2020-supplement.

Author contributions. WY performed the analysis and wrote the original draft. AED provided guidance on the outline of the research and also edited the paper. MP and EJ provided guidance and discussion on Sects. 3 and 4 and participated in the editing.

Competing interests. The authors declare that they have no conflict of interest.

Acknowledgements. We thank William J. Randel, Laura Pan, and Mark Schoeberl for their helpful discussion. We thank the reviewers for their comments. This work was supported by NASA (grant nos. 80NSSC18K0134 and 80NSSC19K0757). This material is also based upon work supported by the National Center for Atmospheric Research, which is a major facility sponsored by the National Science Foundation under Cooperative Agreement no. 1852977. Any opinions, findings, and conclusions or recommendations expressed in this material do not necessarily reflect the views of the National Science Foundation.

Financial support. This research has been supported by NASA (grant nos. 80NSSC18K0134 and 80NSSC19K0757). This material is based upon work supported by the National Center for Atmospheric Research, which is a major facility sponsored by the National Science Foundation under Cooperative Agreement no. 1852977. Any opinions, findings, conclusions, or recommenda- 
tions expressed in this material do not necessarily reflect the views of the National Science Foundation.

Review statement. This paper was edited by Gabriele Stiller and reviewed by two anonymous referees.

\section{References}

Anderson, J. G., Wilmouth, D. M., Smith, J. B., and Sayres, D. S.: UV dosage levels in summer: Increased risk of ozone loss from convectively injected water vapor, Science, 337, 835-839, https://doi.org/10.1126/science.1222978, 2012.

Bergman, J. W., Jensen, E. J., Pfister, L., and Yang, Q.: Seasonal differences of vertical-transport efficiency in the tropical tropopause layer: On the interplay between tropical deep convection, large-scale vertical ascent, and horizontal circulations, J. Geophys. Res.-Atmos., 117, D05302, https://doi.org/10.1029/2011JD016992, 2012.

Bergman, J. W., Fierli, F., Jensen, E. J., Honomichl, S., and Pan, L. L.: Boundary layer sources for the Asian anticyclone: Regional contributions to a vertical conduit, J. Geophys. Res.-Atmos., 118, 2560-2575, https://doi.org/10.1002/jgrd.50142, 2013.

Bowman, K. P.: Large-Scale Isentropic Mixing Properties of the Antarctic Polar Vortex from Analyzed Winds, J. Geophys. Res.Atmos., 98, 23013-23027, https://doi.org/10.1029/93jd02599, 1993.

Bowman, K. P. and Carrie, G. D.: The mean-meridional transport circulation of the troposphere in an idealized GCM, J. Atmos. Sci., 59, 1502-1514, https://doi.org/10.1175/15200469(2002)059<1502:Tmmtco>2.0.Co;2, 2002.

Clapp, C., Smith, J., Bedka, K., and Anderson, J.: Identifying Source Regions and the Distribution of CrossTropopause Convective Outflow Over North America During the Warm Season, J. Geophys. Res.-Atmos., 124, 13750-13762, https://doi.org/10.1029/2019JD031382, 2019.

Cooney, J. W., Bowman, K. P., Homeyer, C. R., and Fenske, T. M.: Ten Year Analysis of Tropopause-Overshooting Convection Using GridRad Data, J. Geophys. Res.-Atmos., 123, 329-343, https://doi.org/10.1002/2017JD027718, 2018.

Dee, D. P., Uppala, S. M., Simmons, A. J., Berrisford, P., Poli, P., Kobayashi, S., Andrae, U., Balmaseda, M. A., Balsamo, G., Bauer, P., Bechtold, P., Beljaars, A. C. M., van de Berg, L., Bidlot, J., Bormann, N., Delsol, C., Dragani, R., Fuentes, M., Geer, A. J., Haimberger, L., Healy, S. B., Hersbach, H., Hólm, E. V., Isaksen, L., Kållberg, P., Köhler, M., Matricardi, M., McNally, A. P., Monge-Sanz, B. M., Morcrette, J.-J., Park, B.-K., Peubey, C., de Rosnay, P., Tavolato, C., Thépaut, J.-N., and Vitart, F.: The ERA-Interim reanalysis: configuration and performance of the data assimilation system, Q. J. Roy. Meteorol. Soc., 137, 553597, https://doi.org/10.1002/qj.828, 2011.

Dessler, A. E. and Sherwood, S. C.: Effect of convection on the summertime extratropical lower stratosphere, J. Geophys. Res.Atmos., 109, D23301, https://doi.org/10.1029/2004jd005209, 2004.

Dessler, A. E., Hanisco, T. F., and Fueglistaler, S.: Effects of convective ice lofting on $\mathrm{H}_{2} \mathrm{O}$ and $\mathrm{HDO}$ in the tropi- cal tropopause layer, J. Geophys. Res.-Atmos., 112, D18309, https://doi.org/10.1029/2007jd008609, 2007.

Dessler, A. E., Schoeberl, M. R., Wang, T., Davis, S. M., and Rosenlof, K. H.: Stratospheric water vapor feedback, P. Natl. Acad. Sci. USA, 110, 18087-18091, https://doi.org/10.1073/pnas.1310344110, 2013.

Dvortsov, V. L. and Solomon, S.: Response of the stratospheric temperatures and ozone to past and future increases in stratospheric humidity, J. Geophys. Res.-Atmos., 106, 7505-7514, https://doi.org/10.1029/2000jd900637, 2001.

Evans, S. J., Toumi, R., Harries, J. E., Chipperfield, M. P., and Russell, J. M.: Trends in stratospheric humidity and the sensitivity of ozone to these trends, J. Geophys. Res.-Atmos., 103, 8715-8725, https://doi.org/10.1029/98jd00265, 1998.

Forster, P. M. and Shine, K. P.: Radiative forcing and temperature trends from stratospheric ozone changes, J. Geophys. Res.Atmos., 102, 10841-10855, https://doi.org/10.1029/96JD03510, 1997.

Forster, P. M. D. F. and Shine, K. P.: Assessing the climate impact of trends in stratospheric water vapor, Geophys. Res. Lett., 29, 1086, https://doi.org/10.1029/2001GL013909, 2002.

Fueglistaler, S.: Stratospheric water vapor predicted from the Lagrangian temperature history of air entering the stratosphere in the tropics, J. Geophys. Res., 110, D08107, https://doi.org/10.1029/2004JD005516, 2005.

Fueglistaler, S., Dessler, A. E., Dunkerton, T. J., Folkins, I., Fu, Q., and Mote, P. W.: Tropical tropopause layer, Rev. Geophys., 47, RG1004, https://doi.org/10.1029/2008RG000267, 2009.

Hanisco, T. F., Moyer, E. J., Weinstock, E. M., St. Clair, J. M., Sayres, D. S., Smith, J. B., Lockwood, R., Anderson, J. G., Dessler, A. E., Keutsch, F. N., Spackman, J. R., Read, W. ., and Bui, T. P.: Observations of deep convective influence on stratospheric water vapor and its isotopic composition, Geophys. Res. Lett., 34, L04814, https://doi.org/10.1029/2006GL027899, 2007.

Herman, R. L., Ray, E. A., Rosenlof, K. H., Bedka, K. M., Schwartz, M. J., Read, W. G., Troy, R. F., Chin, K., Christensen, L. E., Fu, D., Stachnik, R. A., Bui, T. P., and Dean-Day, J. M.: Enhanced stratospheric water vapor over the summertime continental United States and the role of overshooting convection, Atmos. Chem. Phys., 17, 6113-6124, https://doi.org/10.5194/acp17-6113-2017, 2017.

Homeyer, C. R.: Formation of the Enhanced-V Infrared CloudTop Feature from High-Resolution Three-Dimensional Radar Observations, J. Atmos. Sci., 71, 332-348, https://doi.org/10.1175/JAS-D-13-079.1, 2014.

Homeyer, C. R. and Kumjian, M. R.: Microphysical Characteristics of Overshooting Convection from Polarimetric Radar Observations, J. Atmos. Sci., 72, 870-891, https://doi.org/10.1175/JASD-13-0388.1, 2015.

Kim, J., Randel, W. J., and Birner, T.: Convectively Driven Tropopause-Level Cooling and Its Influences on Stratospheric Moisture, J. Geophys. Res.-Atmos., 123, 590-606, https://doi.org/10.1002/2017JD027080, 2018.

Liu, N. and Liu, C.: Global distribution of deep convection reaching tropopause in 1 year GPM observations, J. Geophys. Res., 121, 3824-3842, https://doi.org/10.1002/2015JD024430, 2016.

Livesey, N. J., Read, W. G., Wagner, P. A., Froidevaux, L., Lambert, A., Manney, G. L., Millán Valle, L. F., Pumphrey, H. C., Santee, M. L., Schwartz, M. J., Wang, S., Fuller, R. A., Jarnot, 
R. F., Knosp, B. W., Martinez, E., and Lay, R. R.: Earth Observing System (EOS) Aura Microwave Limb Sounder (MLS), Tech. rep., NASA Jet Propulsion Laboratory, available at: https:// $\mathrm{mls}$.jpl.nasa.gov/data/v4-2_data_quality_document.pdf (last access: October 2020), 2018.

Mote, P. W., Rosenlof, K. H., Mcintyre, E., Carr, E. S., Gille, J. C., Holton, R., Kinnersley, S., Pumphrey, H. C., Russell, M., and Wal, J. W.: An Atmospheric Tape Recorder, J. Geophys. Res.Atmos., 101, 3989-4006, https://doi.org/10.1029/95JD03422, 1996.

Ramaswamy, V., Schwarzkopf, M. D., and Randel, W. J.: Fingerprint of ozone depletion in the spatial and temporal pattern of recent lower-stratospheric cooling, Nature, 382, 616-618, https://doi.org/10.1038/382616a0, 1996.

Randel, W. J., Wu, F., Oltmans, S. J., Rosenlof, K., and Nedoluha, G. E.: Interannual changes of stratospheric water vapor and correlations with tropical tropopause temperatures, J. Atmos. Sci., 61, 2133-2148, https://doi.org/10.1175/15200469(2004)061<2133:ICOSWV>2.0.CO;2, 2004.

Randel, W. J., Zhang, K., and Fu, R.: What controls stratospheric water vapor in the $\mathrm{NH}$ summer monsoon regions?, J. Geophys. Res.-Atmos., 120, 7988-8001, https://doi.org/10.1002/2015JD023622, 2015.

Schoeberl, M. R., Jensen, E. J., Pfister, L., Ueyama, R., Wang, T., Selkirk, H., Avery, M., Thornberry, T., and Dessler, A. E.: Water Vapor, Clouds, and Saturation in the Tropical Tropopause Layer, J. Geophys. Res.-Atmos., 124, 3984-4003, https://doi.org/10.1029/2018JD029849, 2019.

Schwartz, M. J., Read, W. G., Santee, M. L., Livesey, N. J., Froidevaux, L., Lambert, A., and Manney, G. L.: Convectively injected water vapor in the North American summer lowermost stratosphere, Geophys. Res. Lett., 40, 2316-2321, https://doi.org/10.1002/grl.50421, 2013.

Sherwood, S. C. and Dessler, A. E.: On the control of stratospheric humidity, Geophys. Res. Lett., 27, 2513-2516, 2000.

Shindell, D. T.: Climate and ozone response to increased stratospheric water vapor, Geophys. Res. Lett., 28, 1551-1554, https://doi.org/10.1029/1999GL011197, 2001.

Smith, C. A., Haigh, J. D., and Toumi, R.: Radiative forcing due to trends in stratospheric water vapour, Geophys. Res. Lett., 28, 179-182, 2001.

Smith, J. B., Wilmouth, D. M., Bedka, K. M., Bowman, K. P., Homeyer, C. R., Dykema, J. A., Sargent, M. R., Clapp, C. E., Leroy, S. S., Sayres, D. S., Dean-Day, J. M., Paul Bui, T., and Anderson, J. G.: A case study of convectively sourced water vapor observed in the overworld stratosphere over the United States, J. Geophys. Res.-Atmos., 122, 9529-9554, https://doi.org/10.1002/2017JD026831, 2017.

Solomon, D. L., Bowman, K. P., Homeyer, C. R., Solomon, D. L., Bowman, K. P., and Homeyer, C. R.: TropopausePenetrating Convection from Three-Dimensional Gridded NEXRAD Data, J. Appl. Meteorol. Clim., 55, 465-478, https://doi.org/10.1175/JAMC-D-15-0190.1, 2016.
Solomon, S., Rosenlof, K. H., Portmann, R. W., Daniel, J. S., Davis, S. M., Sanford, T. J., and Plattner, G. K.: Contributions of stratospheric water vapor to decadal changes in the rate of global warming, Science, 327, 1219-1223, https://doi.org/10.1126/science.1182488, 2010.

Stenke, A. and Grewe, V.: Simulation of stratospheric water vapor trends: impact on stratospheric ozone chemistry, Atmos. Chem. Phys., 5, 1257-1272, https://doi.org/10.5194/acp-5-1257-2005, 2005.

Sun, Y. and Huang, Y.: An examination of convective moistening of the lower stratosphere using satellite data, Earth Space Sci., 2, 320-330, https://doi.org/10.1002/2015EA000115, 2015.

Ueyama, R., Jensen, E. J., Pfister, L., and Kim, J.-E.: Dynamical, convective, and microphysical control on wintertime distributions of water vapor and clouds in the tropical tropopause layer, J. Geophys. Res.-Atmos., 120, 10483-10500, https://doi.org/10.1002/2015JD023318, 2015.

Ueyama, R., Jensen, E. J., and Pfister, L.: Convective Influence on the Humidity and Clouds in the Tropical Tropopause Layer During Boreal Summer, J. Geophys. Res.-Atmos., 123, 7576-7593, https://doi.org/10.1029/2018JD028674, 2018.

Wang, X., Dessler, A. E., Schoeberl, M. R., Yu, W., and Wang, T.: Impact of convectively lofted ice on the seasonal cycle of water vapor in the tropical tropopause layer, Atmos. Chem. Phys., 19, 14621-14636, https://doi.org/10.5194/acp-19-146212019, 2019.

Waters, J. W., Froidevaux, L., Harwood, R. S., Jarnot, R. F., Pickett, H. M., Read, W. G., Siegel, P. H., Cofield, R. E., Filipiak, M. J., Flower, D. A., Holden, J. R., Lau, G. K., Livesey, N. J., Manney, G. L., Pumphrey, H. C., Santee, M. L., Wu, D. L., Cuddy, D. T., Lay, R. R., Loo, M. S., Perun, V. S., Schwartz, M. J., Stek, P. C., Thurstans, R. P., Boyles, M. A., Chandra, K. M., Chavez, M. C., Chen, G. S., Chudasama, B. V., Dodge, R., Fuller, R. A., Girard, M. A., Jiang, J. H., Jiang, Y., Knosp, B W., Labelle, R. C., Lam, J. C., Lee, K. A., Miller, D., Oswald, J. E., Patel, N. C., Pukala, D. M., Quintero, O., Scaff, D. M., Van Snyder, W., Tope, M. C., Wagner, P. A., and Walch, M. J.: The Earth Observing System Microwave Limb Sounder (EOS MLS) on the aura satellite, IEEE T. Geosci. Remote, 44, 10751092, https://doi.org/10.1109/TGRS.2006.873771, 2006.

World Meteorological Organization: A three-dimensional science: Second session of the commission for aerology, WMO Bull., 4, 134-138, 1957.

Wright, J. S., Fu, R., Fueglistaler, S., Liu, Y. S., and Zhang, Y.: The influence of summertime convection over Southeast Asia on water vapor in the tropical stratosphere, J. Geophys. Res.-Atmos., 116, D12302, https://doi.org/10.1029/2010JD015416, 2011.

Yu, W., Dessler, A., Park, M., and Jensen, E.: Code for "Influence of convection on stratospheric water vapor in the North American Monsoon region", Atmospheric Chemistry and Physics, Zenodo, https://doi.org/10.5281/zenodo.4015534, 2020. 